\title{
MENUMBUHKAN MINAT BACA SEJAK DINI DI TAMAN BACA MASYARAKAT Oleh:
}

\author{
M. Arif Khoiruddin, Imam Taulabi dan Ali Imron \\ Institut Agama Islam Tribakti Kediri \\ Email: arif.khoiruddin84@gmail.com
}

\section{Abstrak}

Membaca merupakan modal utama untuk kemajuan suatu bangsa, oleh karena itu minat baca harus ditumbuhkan pada masyarakat sejak usia dini. Taman baca masyarakat merupakan tempat yang ideal sebagai wahana bermain, belajar dan pengembangan minat baca. Oleh karena itu, pengenalan taman baca masyarakat pada anak sejak usia dini mewacanakan bahwa menghadirkan buku pada anakanak merupakan salah satu upaya untuk menumbuhkaan minat baca pada anak-anak. Dengan tumbuhnya kebiasaan membaca ini dapat mendorong peningkatan kualitas hidup, kreatifitas, kemandirian, daya juang, dan daya saing di masa-masa yang akan datang. Taman Baca Masyarakat dapat menjadi media dalam meningkatkan minat baca pada anak usia dini dengan melakukan beberapa kegiatan, seperti: kegiatan lomba memasak, bazar buku dan baju bekas, lomba menggambar, lomba mewarnai, membaca cerita dan mendongeng, pelatihan membaca cerita dan mendongeng untuk orang tua. Di samping itu ada serangkaan penataan di Taman Baca Masyarakat misalnya, penambahan sarana dan prasarana, menambah buku bacaan untuk anak-anak, pengelolaan sistem pengelolaan taman baca, pengorganisasian taman baca, desain ruangan. Langkah-langkah tersebut dilakukan untuk mengundang anak-anak dan orang tua datang ke taman baca, dengan mereka datang di taman baca, mereka tahu bahwa ada banyak sumber bacaan yang menarik, dengan adanya ketertarikan mereka pada buku dan bahan bacaan lainnya diharpakan dapat mendorong anak-anak untuk gemar membaca. 
Kata Kunci: minat membaca, taman baca masyarakat, anak usia dini, multisensorik

\section{Abstract}

Reading is the capital key in progressing a nation, therefore, interest in reading must be grown in the community from an early age. Reading park community is an ideal place as an idea to play, learning and development of reading interest. Therefore, the introduction of reading park community in children from an early age discourse that presents books to children is one way to foster interest in reading for children. By growth habit of reading can boost the quality life-style, creativity, independence, struggle effort, and competitiveness next time. That reading park community can be a medium in promoting interest in reading for early childhood do several activities, namely: activities cooking contest, a bazaar of books and used clothing, drawing, coloring contest, reading stories and storytelling, training reading stories and storytelling for parents. In addition, there is a series of structuring reading park community for example, the addition of facilities and infrastructure, adding books to children, reading the management of park management system, organizing Reading Park, the design of the room. Such steps undertaken to encourage children and parents to come to the park to read, with their coming in the park to read, they know that there are many sources of interesting reading, with their interest in books and other reading materials are expected to encourage children to love reading.

Keywords: interest in reading, reading park community, early childhood, multisensory 


\section{Latar Belakang}

Berdasarkan survei UNESCO minat baca masyarakat Indonesia baru 0,001 persen. Artinya, dalam seribu masyarakat hanya ada satu masyarakat yang memiliki minat baca. Nilai literasi membaca kita masih sangat rendah. Kita akui, nilai riset Program for Internasional Student Assesment (PISA) rata-rata 493, sementara nilai literasi Indonesia hanya 396. Situasi itu tentu saja menjadi catatan penting dalam dunia pendidikan di tanah air ("Survei UNESCO," 2016). Bagaimana caranya dapat meningkatkan minat baca anak sejak dini?. Shofaussamawati menegaskan adanya taman baca masyarakat ini dapat menumbuhkan minat membaca, karena salah satu faktor rendahnya minat membaca adalah mahalnya harga buku (Shofaussamawati, 2014). Dengan adanya taman baca yang baik di lingkungan masyarakat dapat mendorong minat baca mereka (Karim, 2014). Dengan demikian ketersediaan taman bacaan masyarakat dapat mendorong kualitas sumber daya manusia di masa yang akan datang.

Hasil temuan penelitian menjelaskan bahwa anak-anak usia 5-6 tahun kurang memiliki minat dan kebiasaan membaca(Ruhaena, 2011). Hal ini terjadi karena orang tua lebih banyak mengajarkan keterampilan baca tulis, menyediakan buku dan alat-alat tulis, dari pada mengajak anak membaca cerita, dan bermain kartu/gambar serta membeli buku di toko-toko buku (Ruhaena, 2012). Cara yang dilakukan oleh orang tua ini terlalu tekstual dengan pendekatan kognitif yang menuntut konsetrasi sehingga kurang menyenangkan bagi anak(Ruhaena, 2016). Maka dari itu perlu ada penangan khusus dengan mengembangkan taman baca yang tidak lagi sekedar tempat mengajarkan anak membaca dan menulis tetapi menjadi tempat 
yang dapat mendorong stimulasi anak agar memiliki minat dan kegemaran membaca.

Di beberapa kota ada perpustakaan ramah anak meskipun jumlahnya belum banyak dan belum berskala nasional. Kota Bandung juga telah didirikan Perpustakaan Anak Salman (PAS) yang dibangun atas inisiatif Pembinaan Anak-Anak Salman (PAS) ITB dengan pendanaan dari alumni Salman ITB. Selain buku anak, fasilitas ini juga akan dilengkapi multimedia untuk anak. Di Surabaya, tepatnya di Jalan Mayjen Sungkono, terdapat perpustakaan anak yang merupakan cabang dari Perpustakaan Wilayah Propinsi Jawa Timur, yang didirikan khusus untuk anakanak. Fasilitas yang dibangun meliputi ruang koleksi, ruang baca, ruang bermain, ruang mendongeng, ruang audiovisual, ruang komputer, konter sirkulasi, lobby dan fasilitas pendukung lainnya. Konsep yang digunakan dalam perancangan adalah taman bermain.(Shofaussamawati, 2014)

Menilik dari berbagai contoh perpustakaan anak tersebut di atas, ada beberapa hal yang penting untuk diperhatikan dalam menciptakan minat baca sejak dini. Diharapkan ciri-ciri dan efektifitas taman baca masyarakat/perpustakan di Bandung dan Surabaya ini dapat diterapkan dan dikembangkan dengan dimodifikasi berdasarkan situasi yang ada di kelurahan Kaliombo Kota Kediri dan dapat sangat berguna untuk menumbuhkan minat baca anak. Sedangkan pendekatan pembelajaran taman baca ramah anak akan dilakukan dengan menggunakan model multisensori,(Ruhaena, 2015) dan berbasis pada keluarga yang saat ini menjadi bidang kajian yang berkembang pesat.(Anderson et al., n.d.)

Taman baca masyarakat dapat dijadikan sebagai wahana untuk menumbuhkan minat baca membaca merupakan modal utama untuk kemajuan suatu bangsa, oleh karena itu minat baca 
harus ditumbuhkan pada masyarakat sejak usia dini. Taman baca masyarakat merupakan tempat yang ideal sebagai wahana bermain, belajar dan pengembangan minat baca. Oleh karena itu, pengenalan taman baca masyarakat pada anak sejak usia dini mewacanakan bahwa menghadirkan buku pada anak-anak merupakan salah satu upaya untuk menumbuhkaan minat baca pada anak-anak. Dengan tumbuhnya kebiasaan membaca ini dapat mendorong peningkatan kualitas hidup, kreatifitas, kemandirian, daya juang, dan daya saing di masa-masa yang akan datang.

\section{Minat Membaca}

Minat baca berarti disposisi yang mendorong individu untuk mencari peluang dan sumber daya untuk melaksanakan kegiatan membaca. Ada dua cara untuk memeriksa minat seseorang dalam membaca. pertama seseorang tertarik kegiatan seperti membaca, sehingga ketika dihadapkan dengan buku, individu yang memiliki keinginan yang lebih besar, pengakuan dan mengingat mereka diarahkan pada kegiatan membaca. Kedua, pendekatan lain didasarkan pada isi atau objek yang menarik, bahwa minat stimulus materi untuk mempengaruhi kemampuan individu. Dalam pendekatan ini, lebih terfokus pada faktor-faktor situasional yang mempengaruhi minat baca. Misalnya, jenis bacaan, proses dan memori individu dalam membaca alam ekspositori, rangsangan visual seperti objek atau gambar yang dilihat, timulus pendengaran seperti pernah mendengar percakapan yang berbicara tentang membaca, atau kombinasi dari visual dan pendengaran seperti TV.(Hidi, 2001)

Ada beberapa faktor yang mempengaruhi minat membaca. Pertama, karakteristik teks (bacaan), pada banyak penelitian karakteristik bacaan akan membuat aktivitas membaca 
menjadi lebih menarik. Kedua, pengubahan aspek tertentu pada lingkungan pembelajaran. Unsur ini berkaitan dengan cara teks disajikan, materi yang digunakan untuk mengajarkannya dan regulasi diri dari pembacanya (Siswati, 2010).

\section{Taman Baca Masyarakat (TBM)}

Taman Bacaan Masyarakat adalah lembaga yang menyediakan berbagai jenis materi pembelajaran yang dibutuhkan oleh masyarakat. Sebagai tempat untuk membina melek dan belajar, serta tempat untuk mendapatkan informasi untuk publik (Departemen Pendidikan Nasional, 2008). Taman baca adalah sumber informasi bagi masyarakat, baik masyarakat dan komunitas kelas menengah dan menengah atas. Mulai dari penempatan RW, Desa, tempat rekreasi, kebun kota dan lainnya. Sangat efektif, efisien dan terjangkau bagi seluruh masyarakat.(Dewi, 2010)

Untuk meningkatkan peran TBM dalam menumbuhkan minat baca masyarakat disekitar TBM perlu ada perbaikan. Perbaikan ini diharapkan akan memotivasi masyarakat untuk berkunjung dan membaca koleksi TBM. Perbaikan yang dapat dilakukan antara lain: Pertama, koleksi TBM terus ditingkatkan baik dari segi kuantitas maupun kualitas. Kedua, sarana atau perabot TBM perlu dilengkapi, TBM dapat dilengkapi dengan pendingin udara, televisi dan computer multimedia. Ketiga, masalah sumber daya manusia TBM juga perlu mendapat perhatian. TBM harus dikelola dengan baik oleh tenaga yang memiliki keahlian ilmu perpustakaan, dokumentasi dan informasi. eempat, peningkatan dana untuk mengatasi masalah keterbatasan koleksi, sarana TBM. 


\section{Perkembangan Anak Usia Dini dan Cara Mereka Belajar}

Kebiasaan membaca perlu ditumbuhkan dan ditingkatkan dari sejak kecil. Orang tua yang menyisihkan waktu untuk membaca dengan anak, memberikan permulaan yang baik untuk memahami literasi merupakan contoh yang ideal untuk mencapai prestasi pendidikan yang baik. Banyak penelitian yang menunjukkan anak yang berhasil mencapai prestasi literasi di sekolah biasanya datang dari lingkungan rumah yang menyediakan buku, dan orang tua mempunyai kesempatan untuk membaca dengan anak, serta melihat orang tua dan saudaranya melakukan aktivitas membaca (Bingham and Pennington, 2007). Mulyani berpendapat bahwa tingkat perkembangan seseorang yang paling menguntungkan untuk pengembangan minat membaca adalah pada masa peka yaitu sekitar usia 5 - 6 tahun. Kemudian minat membaca ini akan berkembang sampai dengan masa remaja (Mulyani, 1981).

Sebelum melakukan itu orang tua atau orang dewasa perlu memahami karakteristik anak. Agar cara-cara yang dilakukan dalam proses belajar membaca tidak menjadi beban bagi anak itu sendiri sehingga menggangu aspek perkembangan lainnya. Maka orangtua perlu memahami anak dengan perkembangan usia dan kebutuhan belajar mereka. Untuk bisa mengerti keinginan mereka maka orang tua harus menyesuaikan dengan cara melihat kepentingan dari sudut pandangn mereka (Nur'aini, 2008).

Maka perlu adanya pemahaman orangtua dan guru terhadap perkembangan anak usia 5 sampai dengan 6 tahun. Pada usia itu, anak memiliki fase perkembangan yang berbeda;

(1) perkembangan fisiologis; (2) perkembangan kognitif; (3) perkembangan psikososial; (4) perkembangan bahasa dan komunikasi; dan (5) perkembangan kecerdasan jamak. 


\section{Desain Pendampingan}

Desain pendampingan yang dilakukan menggunakan model pengabdian berbasis PAR (Participatory Action Research). Model pengabdian berbasis PAR ini memiliki tiga Variabel kunci yaitu, berpartisipasi, aksi dan penelitian. Dari ketiga prinsip PAR itulah dosen (yang melakukan pengabdian) bisa bersama-sama masyarakat melakukan identifikasi masalah, perencanaan, dan tindakan untuk menyelesaikan persoalan-persoalan yang mereka hadapi. Di samping itu PAR memiliki nuansa penelitian kritik yang konstruktif terhadap kondisi masyarakat, sehingga menjadi tugas independent dosen sebagai bentuk laporan pertangung jawaban atas keterlibatan mereka terhadap proses perubahan yang dilakukan beserta masyarakat tersebut.

\section{Tempat dan Subjek Dampingan}

Kegiatan ini dilaksanakan di taman baca masyarakat Kelurahan Kaliombo Kata Kediri. Pendampingan ini menjadi penting karena berbasis komunitas yang dinamai 'Komunitas Taman Baca Puri Anjali. Dalam komunitas tersebut ada beberapa anak yang terlibat dalam kegiatan belajar bersama, membaca, bercerita, mendongen dan bermain. Komunitas ini memilih segmen anak-anak, keterlibatan tim ini memberikan penguatan dalam menumbuhkan minat baca sejak anak usia dini 4-7 tahun, karena usia ini menetukan perkembangan anak dimasa-masa yang akan datang. Di samping, ada stakeholder kunci yang berperan penting sehingga program ini akan dapat terrealisasi sesuai yang diharapkan. 


\section{Strategi Aksi}

Upaya untuk mengangkat program peningkatan minat dan kegemaran membaca perlu melibatkan unsur-unsur berikut ini: (a) anak didik usia di bawah tujuh tahun, (b) tokoh masyarakat, (c) orang tua, (d) lingkungan masyarakat, (e) lembaga-lembaga masyarakat yang berminat terhadap pengembangan minat dan kegemaran membaca, (f) pemerintah melalui berbagai program yang dikembangkan posyandu, dan (g) komunitas lainnya. Langkah awal yang dilakukan oleh tim, melakukan komunikasi dengan lebih intensif dengan tokoh masyarakat yang sebagai pemilik komunitas taman baca Puri Anjeni. Tim selanjutnya melakukan koordinsai dengan tim dan beberapa orang relawan.

Adapun tindakan yang akan dilakukan dalam pengembangan taman baca masyarakat ramah anak meliputi halhal sebagai berikut:

a. Penataan status organisasi taman baca masyarakat,

b. Pendanaan yang memadahi yang dapat digunakan untuk operasional taman baca masyarakat,

c. Tempat yang representative dan ramah anak,

d. Koleksi bahan pustaka perlu disesuaikan dengan kebutuhan,

e. Peralatan dan perlengkapan, perlu disesuaikan dengan kebutuhan taman baca masyarakat sehingga taman baca dapat berjalan dengan baik,

f. Tenaga mempunyai kualifikasi yang memadahi untuk pengelolaan taman baca masyarakat,

g. Layanan taman baca masyarakat disesuaikan dengan kebutuhan,

h. Promosi dilakukan berbagai cara agar anak dan masyarakat tertarik berkunjung dan membaca; (1) Lomba menggambar untuk paud dan TK/RA, (2) Lomba mewarnai untuk paud dan 
TK/RA, (3) Mendengarkan cerita, dan (4) Kegiatan pelatihan membaca cerita dan mendongeng untuk ibu rumah tangga,

i. Gerakan membaca 20 menit untuk anak batuta,

j. Gerakan mematikan televisi jam 18.00-20.00,

k. Gerakan literasi dalam Keluarga.

\section{Analisa Data}

Dalam analisis ini, ada lima langkah yang peneliti lakukan, yaitu; pertama, memilih pola hubungan semantik tertentu atas dasar informasi yang tersedia dalam catatan harian peneliti di lapangan. Kedua, memilih kesamaan data dari catatan harian peneliti di lapangan. Ketiga, memilih konsep-konsep induk dan kategori-kategori simbolis dari domain tertentu yang sesuai dengan suatu pola hubungan semantik. Keempat, menyusun pertanyaan-pertanyaan struktural untuk masing-masing domain. Dan kelima, menyusun daftar keseluruhan domain dari seluruh domain yang ada (Spradly, 2006).

\section{Pelaksanaan Pengabdian}

\section{Menyediakan Bahan Bacaan Yang Menarik Anak}

Tim menyediakan bahan bacaan yang menarik bagi anak. Langkah ini dilakukan dalam rangka mendukung minat dan kunjungan warga masyarakat khususnya anak-anak. TBM Puji Anjali melakukan penataan dalam berbagai sarana pendukung tempat belajar yang ideal bagi anak. Dari alasan itu tim melakukan penataan yang dilakukan pertama adalah membeli alat permainan anak berupa Engklek dan permainan ular tangga Educatif permainan ini berfungsi untuk mengembangkan kemampuan motorik halus dan kasar anak. Di samping itu permainan ini berfungsi untuk menjalin interaksi sosial antara anak, sikap disiplin dan patuh pada aturan. 
Penambahan buku bacaan dengan membeli buku cerita anak berbahasa inggris di BBW Surabaya. Pembelian buku komik dan perlengkapan buku lainya di Togamas Kediri dan pembelian buku anak karya Watiek Ideo. Penambahan buku-buku tersebut dalam rangka menambah koleksi TBM Puri Anjali dan menambah sumber informasi bagi masyarakat. Disamping itu penambahan koleksi buku juga berhubungan dengan realisasi program-program berikutnya.

\section{Mendesain Taman Baca Masyarakat}

Penataan berikutnya dari segi interior dan ekterior ruangan. Anak akan tumbuh minat dan ketertarikan dalam membaca apabila suasana lingkungan disekitarnya mendukung kegiatan tersebut. Jika lingkungan yang ada mendukung sebagai tempat belajar anak-anak akan dapat berlama-lama. Dengan demikian tim membeli beberapa perangkat seperti rak tempel di dinding, meja dan kursi baca. Sedangkan untuk mejadikan ruangan lebih terkesan menarik tim membuat desain ruangan. Dinding yang ada dilukis agar membuat kesan menarik, indah dan nyaman bagi anak yang berkunjung di taman baca.

\section{Lomba Memasak}

Kegiatan ini dilakukan dalam rangka mengumpulkan warga masyarakat dan menjalin solidaritas anak-anak yang sudah tergabung dalam Komunitas Taman Baca Anak Puri Anjali dan mengumpulkan lebih banyak lagi anak-anak untuk terlibat dalam kegiatan yang positif.

Lomba memasak dilakukan secara kelompok yang terdiri dari tiga anak. Kegiatan lomba ini, sebagai upaya dalam rangka mempertahankan relasi antara anak, ketika kegiatan-kegiatan yang berbasis buku anak-anak sudah bosan dan kurang diminati 
lagi. Kegiatan ini sebagai penarik minat anak agar tidak mengalami kejenuhan dalam kegiatan belajar.

Pada sisi lain kegiatan memasak juga memiliki manfaat lain, misalnya: melatih kerjasama, melatih kekompakan, melatih ketrampilan memasak, terbiasa untuk berkompetisi dan dapat menerima kemenangan yang dicapai oleh kelompok lain (mereka belajar untuk dapat menerima kekalahan). Kegiatan memasak dapat meningkatkan kemampuan motorik halus anak, selain itu terlihat juga bahwa anak menjadi termotivasi untuk berkembang dan berkreasi. Hal ini terbukti dengan adanya peningkatan anak cenderung lebih semangat belajar karena kegiatan pembelajaran yang menyenangkan dan melibatkan anak untuk berpraktek secara langsung.

\section{Bazar Buku dan Baju Bekas}

Kegiatan bazar buku dilakukan dengan melibatkan beberapa relawan yang memiliki komitmen dalam mengembangkan taman baca yang ada di kota Kediri dan beberapa lembaga yang memiliki kepedulian pada anak-anak. Selanjutnya buku yang terkumpul dipilih berdasarkan kriteria: buku anak-anak Islami dan buku pendidikan karakter, serta yang tema tentang cerita rakyat, cerita bergambar dan buku mewarnai. Dalam bazar buku ini terkumpul sekitar 250 buku dengan 100 judul buku yang terdiri dari $25 \%$ buku cerita rakyat, $25 \%$ buku anak islami, dan 50 \% buku anak bergambar kategori lainnya (junior novel, mewarnai gambar dan komik).

Pada pelaksanaan bazar buku beberapa pengunjung datang dari masyarakat umum yang ada di sekitar taman baca. Bazar buku secara umum terbuka untuk semua masyarakat di keluarahan Kaliombo ataupun luar. Para pengunjung menyatakan ketertarikan untuk melihat dan membaca buku- 
buku. Mereka mengungkapkan buku-buku anak yang dipamerkan menarik. Jenis buku yang banyak diminati orang tua adalah buku cerita bergambar yang narasinya sesuai dengan gambar, ilustrasi maupun alur kisahnya menarik.

Kebanyakan pengunjung yang datang dari warga dan anak-anak di sekitar Taman Baca Masyarakat Puri Anjali. Kegiatan bazar buku dimaksudkan sebagai sarana untuk memperkenalkan keberadaan dari Taman Baca Masyarakat Puri Anjali yang belum banyak dikenal oleh masyarakat sekitar. Bahwa di TBM Puri Anjali menyediakan beberapa buku yang dapat dibaca, dipinjamkan secara gratis. Disamping itu, bazar buku ini dapat dijadikan ajak belajar anak-anak. Mereka dapat memanajemen, melatih kemampuan berinteraksi dengan orang lain baik dewasa maupun anak-anak, melatih kecerdasan matematik dan melatih kemampuan berkomunikasi verbal maupun lisan.

Bazar baju bekas bertujuan untuk menarik masyarakat agar berkunjung di TBM Puri Anjali. Bazar ini menampung baju bekas layak pakai dari orang-orang yang kebingungan membuang baju mereka yang sudah tidak terpakai namun masih layak untuk digunakan. Disamping itu bazar juga menyediakan baju-baju murah yang dapat terjangkau masyarakat di sekitar Kaliombo. Harga baju yang ditawarkan mulai kisaran harga Rp. 15.000 (untuk jenis kaus) sampai dengan Rp. 75.000 (untuk jenis gamis dan baju panjang). Jenis barang yang dijual baju anak, baju dewasa, baju remaja, baju cewek, baju cowok, jilbab, tas, sandal, dan sepatu.

Manfaat kegiatan ini bagi anak adalah melatih anak-anak melayani pembeli dengan baik. Mereka dapat belajar berkomunikasi dengan menawarkan barang dagangannya, tentu dengan menggunakan tata cara dan bahasa yang santun dan baik 
agar barang daganngaya diminati pembeli. Mereka melayani ada yang menjadi kasir, menentukan harga, melabeli harga, meletakan di hanger dan melibatkan orang tua anak-anak di rumah.

Penjualan baju bekas menjadi satu kesatuan dengan bazar buku. Bazar baju bekas menjadi buruan warga. Tak peduli kualitas, asal harga murah, warga tetap berkunjung di bazar baju. Harga murah dan layak pakai. Tim menyediakan bazar baju murah sehingga dapat dijangkau masyarakat luas dan dapat menarik kedatangan orang tua. Rupanya banyak pengunjung tergoda dengan harga murah Dengan harga yang terbilang murah meriah, banyak baju yang terjual. Sisa baju yang tidak terjual disumbangkan kepada masyarakat di daerah pegunungan di sekitar kecamatan Tarokan Kabupaten Kediri. Dari hasil penjualan buju bekas selama satu hari mendapatkan uang 1 juta lebih.

\section{Lomba Menggambar Untuk Paud, TK/RA dan SD Kelas 1-3}

Kegiatan lomba menggambar memiliki beberapa tujuan, yakni: sebagai media untuk mengumpulkan warga (orang tua dan anak); pengembangan imajinasi anak, pengembangan gerak kognitif, dan motorik halus; mengembangkan bakat anak; stimulus kegiatan belajar; dan interaksi anak dengan orang lain dan menumbuhkan sikap kompetitif (kecerdasan emosional).

\section{Lomba Mewarnai Untuk Paud Dan TK/RA}

Mewarnai adalah kegiatan yang menyenangkan bagi anak-anak. Selain itu, aktivitas mewarnai juga sudah menjadi bagian dari kehidupan anak, bukan hanya sebagai kegiatan untuk mengisi waktu kosong anak, tapi juga sebagai aktualisasi diri anak dalam bidang seni. Di samping itu, kegiatan ini 
memiliki manfaat, seperti: media berekspresi, mengenal warna, media terapi, keterampilan motorik, melatih konsentrasi, garis batas, menyelesaikan pekerjaan.

\section{Mendengarkan Cerita dan Dongeng}

Kegiatan ini dilaksankan sebagai jawaban atas realita yang terjadi pada masyarakat. Banyak orang tua yang meninggalkan budaya bercerita dan mendongeng untuk anak. Sekarang para orang tua lebih banyak memanfaatkan teknologi digital untuk menghibur buah hati mereka. Padahal cerita dan dongeng yang dikisahkan langsung dari mulut orang tua merupakan hiburan yang tepat untuk anak. Selain menghibur, aktivitas ini juga memiliki banyak manfaat yang bisa membantu tumbuh kembang anak di masa mendatang. Dengan demikian kegiatan ini perlu dilakukan.

Bercerita dan mendongeng memiliki banyak manfaat untuk anak. Seperti (1) memperkaya kosakata anak; membangun kedekatan emosional antara pendidik dengan anak; (3) mendengarkan sebuah cerita dan dongeng bisa menstimulasi daya imajinasi dan berpikir agar anak tumbuh menjadi anak yang kreatif, melatih kemampuan mendengar; (4) usai membacakan dongeng, dilanjutkan dengan bertanya kepada anak mengenai cerita tersebut atau membiarkannya untuk bercerita ulang, hal ini bermanfaat untuk melatih daya ingatnya; (5) makin banyak anak mendengar, maka makin mudah anak untuk berbicara; (6) saat mendongeng, tertawa bersama dan bermanja-manja, hal itu bisa mempererat hubungan antara anak, sarana hiburan dan penarik perhatian; (7) media penyampai pesan/nilai mora dan agama yang efektif; (8) membantu proses peniruan perbuatan baik tokoh dalam cerita dan membangun watak mulia; dan (9) menggugah minat baca. 


\section{Kegiatan Pelatihan Membaca Cerita dan Mendongeng Untuk Ibu Rumah Tangga}

Orang tua pada umumnya tidak memiliki keterampilan dalam membacan cerita atau mendongen, sehingga kegiatan membaca cerita atau mendongeng tidak menjadi aktivitas yang rutin dilakukan orang tua di rumah ketika berkumpul dengan anaknya disela-sela waktu istirahat. Terlebih ketika orang tua lebih memberikan pilihan hiburan berupa alat-alat berteknologi. Orang tua dalam menjalin interaksi dengan anaknya juga menggunakan teknologi, sehingga drastis aktivitas bercerita dan mendongen tidak pernah dilakukan. Disamping itu, orang tua juga memiliki keterbatasan atas sumber-sumber bacaan cerita untuk anak, keterbatasan kisa-kisa yang dapat jadikan sebagai bahan untuk mendongen.

Maka dari sinilah pelatihan membaca cerita dan mendongeng ini dilakukan kepada orang tua. Kegiatan ini setidaknya dapat memberikan bekal pada orang tua mencakup beberapa hal: persiapan bercerita, praktek bercerita, dan intonasi suara dan gerakan mata sangat menentukan cerita.

\section{Pembahasan}

\section{Dinamika Keilmuan}

Manajemen Taman Baca Masyarakat. Manajemen diperlukan adanya proses penataan TBM, secara umum manajemen terdiri dari, perencanaan, pengorganisasian, kepemimpinan, dan pengendalian. Manajemen TBM agar elemen yang terlibat dalam TBM mampu melakukan tugas dan pekerjaannya dengan baik dan benar. Managemen Taman Baca Masyarakat dalam mencapai tujuan, diperlukan sumber daya manusia, sumber dana, sistem, fisik, perlengkapan, informasi, 
ide, dan teknologi. Elemen-elemen tersebut dikelola melalui proses manajemen yang meliputi perencanaan, pengorganisasian, kepemimpinan, dan pengendalian, yang diharapkan mampu mengahsilkan produk berupa barang atau jasa yang dapat dimanfaatkan oleh masyarakat pengguna.

Perkembangan anak, usia anak 5 sampai dengan 6 tahun merupakan masa keemasan bagi perkembangan fisik dan mental anak. Pada masa ini anak sangat sensitif menerima segala pengaruh yang diberikan oleh lingkungannya. Maka dari itu orang tua dan pihak-pihak lain perlu memiliki wawasan tentang perkembangan dan pengembangan anak yang bersangkutan, khususnya dalam menyikapi bakat, minat dan kecerdasan anak. Menyikapi persoalan kecerdasan anak orang tua terkadang berpikir secara parsial, mengukur kecerdasan anak hanya dilihat dari satu sisi yaitu: kecerdasan ligustik atau kecerdasan logika matematik. Tentu pemahaman seperti di atas, berdampak pada pemberian perlakukan pada anak baik di rumah bagi orangtua. Tentunya perlakuan yang tidak tepat akan berdampak pada psikis anak dan perkembangan mereka di masa yang akan datang.

Desain dan penataan ruangan, Penataan TBM sangat dibutuhkan untuk mengoptimalkan semua kegiatan. TBM menyediakan bahan pustaka dengan lengkap, fasilitas perpustakaan memadai tanpa penyediaan tata ruang baca yang baik akan membuat orang kurang tertarik berkunjung. Tata ruang TBM harus dirancang sedemikian rupa. Seperti memperhatikan pada lay out, perabot, ruang baca serta sirkulasi ruangnya. Selain itu juga perlu dirancang masalah pengkodisian ruang maupun lingkungan.

Pendidikan orang tua, ditujukkan pada orang tua yang memiliki anak batita. Pemenuhan kebutuhan orang tua adanya 
keinginan diri untuk melengkapi dan membelajarkan anaknya sejak dini dengan cara yang tepat. Orang tua perlu belajar keterampilan-keterampilan dasar cara bercerita dan mengajari anaknya mengenal huruf. Keterampilan tersebut tidak pernah diajarkan dalam lembaga pendidikan formal, sehingga perlu dibelajarkan dalam kegiatan pelatihan. Jika seseorang mengharapkan suatu pengetahuan, maka ia mencarinya, baik dengan cara menanyakan secara langsung atau mencari sumber lain.

\section{Kegiatan Menggambar}

Menggambar dapat dikelompokkan masuk kedalam kegiatan bermain dengan cara membangun, misalnya dengan pensil, krayon dan kertas gambar untuk membuat rumah, kereta api, jembatan, hewan secara grafis. Anak akan menarik garis lengkung, lurus dengan bermacam bentuk yang diinginkan yang merupakan bentuk grafis dua dimensi. Penyaluran kreativitas anak dengan menggambar untuk menyalurkan perasaan dan bukan untuk menciptakan keindahan (Moeslichatoen, 2004).

Proses menciptakan sebuah gambar yang diinginkan inilah yang paling penting bukan pada hasil akhir. Anak yang menggambar menjadi wujud ekspresi kesadaran anak. Gambar yang dihasilakan diekspresikan bersifat simbolik. Anak menggambar sesuatu apa yang diingatannya dan tidak memperhatikan kesesuian, proporsi, perspektif maupun.

\section{Kebersamaan dalam Mengembagkan Pengetahuan}

Berbagai kegiatan yang terjadi dan dilakukan di taman baca masyarakat dapat mendorong terjadinya interaksi antara sesame. Intersaksi itu sendiri menjadi dasar diawalinya proses belajar pada anak. Jika menggunakan teori Vygosky maka dapat 
diuraikan sebagai berikut; Pertama pembelajaran sosial, bahwa anak melalui interaksi bersama dengan teman yang lebih cakap. Kedua, ZPD (zone of proximal development), anak tidak dapat memecahkan masalah sendiri, tetapi dapat memecahkan masalah itu setelah mendapat bantuan dari temannya. Ketiga, masa magang kognitif (cognitif apprenticeship), anak memperoleh kecakapan intelektual melalui interaksi dengan orang yang lebih ahli, orang dewasa, atau teman yang lebih pandai. Keempat, pembelajaran termediasi (mediated learning), anak diberi masalah yang kompleks, sulit, dan realistik, dan kemudian diberi bantuan secukupnya dalam memecahkan masalah.

Teori ini menekankan interaksi antara anak dalam proses pembelajaran dan penekanannya pada lingkungan sosial pembelajaran, anak berinteraksi dalam proses bermain (mewarnai, menggambar, mendengarkan cerita dan dongen). Teori ini menekankan fungsi kognitif manusia berasal dari interaksi sosial masing-masing individu atau kelompok dalam konteks budaya (teman dengan berbagai karakter dan latar belakang yang berbeda). Proses pembelajaran terjadi saat anak menanyakan atau mengkonfirmasi hal-hal yang belum dipahami, atau ketidaksamaan dalam mempresepsikan sebuah masalah. Scaffolding sebagai suatu proses dimana anak dibantu untuk memahami suatu masalah tertentu di luar kemampuannya melalui bantuan orang lain yang memahaminya.

\section{Mewarnai dan Menggambar Mengasah Keterampilan Anak}

Kegiatan mewarnai pada anak-anak prasekolah dapat mendorong kemampuan motorik halus. Anak yang mewarnai tangan dan jari-jemarinya mengambangkan keterampilan menggambar, memotong, mewarnai, dan melipat. Mereka 
310 | Arif Khoiruddin, Imam Taulabi, Ali Imron | Menumbuhkan minat baca

dapat memakai dan melepas baju, dan menggunakan perkembangan motorik halusnya untuk menjadi lebih mandiri.

Masa kecil sering disebut waktu yang ideal atau tepat untuk mempelajari keterampilan motorik. Hal tersebut dikarenakan (1) tubuh anak lebih lentur ketimbang tubuh orang dewasa, (2) anak belum memiliki keterampilan yang akan berbenturan dengan keterampilan barunya, (3) anak lebih berani waktu kecil daripada usia dewasa, (4) anak menyukai kegiatan pengulangan untuk melatih ototnya, serta (5) anak memiliki waktu yang lebih banyak untuk belajar kegiatan barunya (Hurlock, 2007).

Keterampilan motorik yang terkoordinasi baik, otot yang lebih kecil memainkan peran yang besar. Sedangkan pengertian motorik halus adalah gerakan yang hanya melibatkan bagianbagaian tubuh tertentu saja dan dilakukan oleh otot-otot kecil seperti keterampilan menggunakan jari-jemari tangan dan gerakan pergelangan tangan. Gerakan ini membutuhkan koordinasi mata dan tangan yang cermat (Hurlock, 2007). Menggambar dan mewarnai dapat disimpulkan dapat meningkatkan kemampuan motorik halus anak. Hal ini dapat dilihat setelah anak melakukan beberapa latihan, terjadi peningkatan kemampuan motorik halus anak pada setiap kategori berkembang sangat baik untuk masing-masing aspek yang diamati.

Anak pada usia 3 tahun telah memiliki kemampuan untuk mengambil objek terkecil di antara ibu jari dan telunjuk untuk beberapa waktu, tetapi mereka masih melakukannya. Sedangkan pada usia 4 tahun, koordinasi motorik halus anak lebih tepat (Hurlock, 2007). Kompetensi perkembangan keterampilan motorik halus dalam penelitian ini adalah (1) menggunting mengikuti pola garis lurus, (2) mengenakan dan membuka 
Arif Khoiruddin, Imam Taulabi, Ali Imron | Menumbuhkan minat baca | 311

kancing baju, dan (3) menggambar dan mewarnai menggunakan krayon.

\section{Mewarnai dan Menggambar Sebagai Terapi}

Mewarnai gambar adalah terapi permainan gambar untuk mengembangkan kreativitas pada anak, mengurangi stress dan kecemasan serta meningkatkan komunikasi (Supartini, 2004). Manfaat mewarnai sebagai berikut: 1) media berekspresi, 2) mengenal perbedaan warna, 3) merupakan media terapi, 4) melatih kemampuan koordinasi, 5) dapat membantu menggenggam pensil, 6) membantu kemampuan motoric, 7) meningkatkan konsentrasi, 8) dapat melatih anak mengenal garis bidang, 9) melatih anak membuat target, 10) sebagai media komunikasi. Tata cara mewarnnai, 1) anak diberikan buku mewarnai dengan pensil warna, 2) anak diperkenalkan dengan gambar-gambar, 3) anak diminta mengenali bagian-bagian gambar, 4) anak diminta mewarnai gambar, 5) anak harus menyelesaikan tugas.

Bermain memungkinkan anak terlepas dari ketegangan yang dialami selama. Ketika anak melakukan permainan, anak akan dapat mengalihkan rasa sakitnya pada permainannya (distraksi) dan relaksasi melalui kesenangannya melakukan permainan (Supartini, 2004). Permainan yang tepat untuk anak pra sekolah (4-6 tahun) dengan mewarnai gambar, karena dapat mendorong aspek perkembangan anak dan mendorong aktifitas dan kreatifitas anak. Mewarnai gambar adalah aktifitas anak yang disukainya, dan merupakan salah satu cara yang tepat untuk menghadapi dan mengatasi stress. Dengan menggambar atau mewarnai sebagai suatu permainan yang "nondirective" yang memungkinkan anak untuk bebas berekspresi dan sangat “therapeutic". Mengekspresi dengan menggambar/ mewarnai 
312 | Arif Khoiruddin, Imam Taulabi, Ali Imron | Menumbuhkan minat baca

gambar memberikan cara pada anak untuk berkomunikasi, tanpa menggunakan kata.

\section{Bercerita dan Pengembangan Kecerdasan Anak}

Bercerita merupakan metode yang efektif dan paling banyak digemari pada usia anak. Alasannya: (1) cerita pada umumnya lebih berkesan dari pada metode lain. Bercerita mendorong anak-anak mengebangkan imaninasinya, karena pesan yang disampaikan dalam bentuk verbalisme yang mendorong anak-anak untuk berpikir, mengira-ngira dan menebak. Anak-anak diajak berpikir membayangkan sesuatu sehingga pada umumnya cerita terekam jauh lebih kuat dalam memori manusia; (2) melalui cerita anak diajarkan mengambil pesan, nilai dan hikmah. Bercerita akan membuat anak merasa lebih nyaman dari pada diceramahi dengan nasehat (Muallifah, 2013), dengan bercerita anak dapat membedakan tentang perilaku baik atau buruk, belajar tentang perjuangan dan kesetiakawanan (Rahman, 2013); (3) melalui cerita terjadi peningkatan kemampuan berbicara anak (Marini et al., 2015); (4) melalui cerita memiliki peran penting pada diri anak dalam pengembangan rasa empati (Kumoro, 2015).

Bercerita dapat menstimulasi berbagai kecerdasan anak pada usia dini. Bercerita mampu meningkatkan kecerdasan bahasa anak, menanamkan moral pada anak dan kreatifitas. Namun hal yang perlu diperhatikan bahwa tahap kognitif anak usia dini berada pada tahap operasional kongkrit, dengan demikian bentuk dan materi cerita yang dijadikan dalam bercerita harus disesuaikan dengan kemampuan anak dan perkembangan anak. 


\section{Bercerita Mengajarkan Moral}

Bercerita mengandung unsur teladan yang bisa diberikan pada anak melalui ceritanya. Orangtua pasti menginginkan anak memiliki sikap dan prilaku moral yang baik. Moral yang positif pada anak tidak mungkin dengan memberikan ceramah dan memarahi jika anak atas kesalahannya. bercerita adalah menjadi salah satu metode yang disukai anak. Orangtua dapat memberikan cerita yang mengandung unsur moral dan mengajarkan nilai moral yang baik pada anak. Contohnya, sambil bercerita orangtua mengajarkan anak untuk berdo'a setiap sebelum dan sesudah makan, berterimakasih dan bersyukur dengan nikmat yang diterima, dan bersikap sopan santun kepada orang lain. Melalui cerita anak tanpa merasa diguruhi dan dinasehati dengan kata-kata yang menakutkan. Dengan demikian orangtua bisa mengajarkan dan menanamkan moral kepada anak sejak usia dini. Metode bercerita hendaknya menyesuaikan dengan kemampuan kognitif anak. Jadi cerita yang disampaikan haruslah menyesuaikan tingkat kemampuan kognitif anak (Muallifah, 2013).

\section{Taman Baca Masyarakat dan Minat Baca}

Kegiatan yang ada di TBM adanya peningkatan minat baca anak. Dengan adanya stimulus melalui kegiatan menggambar, mewarnai, membaca cerita dan mendongen menjadi langkah awal untuk mengenalkan anak dengan bukubuku bacaan. Setelah mereka kenal dengan beberapa bacaan akan mendorong anak menumbuhkan minat membacanya.

Salah satu tanda bahwa sebuah masyarakat merupakan komunitas pembelajar, masyarakat yang sadar dan melek informasi, serta masyarakat intelektual adalah adanya taman baca masyarakat yang memadai dengan gegap gempita 


\section{4 | Arif Khoiruddin, Imam Taulabi, Ali Imron | Menumbuhkan minat baca}

pengunjung dan aktivitas yang berkaitan dengan kepustakaan dan intelektualisme. Namun semuanya itu agaknya masih jauh panggang dari api ketika kita meliht kondisi taman baca masyarakat dan minat masyarakat Indonesia untuk memanfaatkan taman baca masyarakat.

Realitas yang ada, budaya menonton televisi telah melemahkan budaya baca masyarakat. Televisi melemahkan daya analisis dalam ranah kognitif penontonnya karena otak dimanjakan dengan informasi yang bersifat instan. Berbeda dengan buku dan teks tertulis lainnya, pembaca diajak untuk menganalisis teks, menggali hakikat dan makna dan bermain imajinasi. Hal ini menyebabkan otak terlatih untuk menganalisis dan mengkritisi teks, otak tidak dimanjakan dan akan semakin kuat daya analisisnya. Walaupun begitu masyarakat yang sebagian besar bermental instan dan ingin dimanja tentu tidak mempedulikan hal itu, mereka takkan lebih memilih buku daripada televisi. Ketika sebagian besar masyarakat sudah mempunyai persepsi kurang penting pada bahan pustaka terlebih lagi perpustakaan pun dianggap sama. TBM Tidak menjadi tujuan utama masyarakat dalam mencari dan mendapatkan informasi.

Ada dua cara untuk memeriksa minat seseorang dalam membaca. pertama seseorang tertarik kegiatan seperti membaca, sehingga ketika dihadapkan dengan buku, individu yang memiliki keinginan yang lebih besar, pengakuan dan mengingat mereka diarahkan pada kegiatan membaca. Kedua, pendekatan lain didasarkan pada isi atau objek yang menarik, bahwa minat stimulus materi untuk mempengaruhi kemampuan individu. Dalam pendekatan ini, lebih terfokus pada faktor-faktor situasional yang mempengaruhi minat baca. Misalnya, jenis bacaan, proses dan memori individu dalam membaca alam 
ekspositori, rangsangan visual seperti objek atau gambar yang dilihat, timulus pendengaran seperti pernah mendengar percakapan yang berbicara tentang membaca, atau kombinasi dari visual dan pendengaran seperti TV (Hidi, 2001).

Pemisahan dari dua pendekatan menjadi minat yang sifatnya individual dan situasional. Minat yang sifatnya individual berkembang sangat lambat, cenderung bertahan lebih lama dan dikaitkan dengan peningkatan pada nilai dan pengetahuan yang dimiliki individu tersebut. Sedangkan minat yang sifatnya situasional tidak mempunyai pengaruh jangka panjang pada pengetahuan dan nilai yang dibentuk individu. Selain itu, minat yang bersifat individual biasanya dihubungkan dengan afek yang positif, sedangkan minat yang situasional tidak selalu berhubungan dengan afek yang positif (Hidi, 2001).

Ada beberapa faktor yang mempengaruhi rendahnya minat membaca pada anak. Pertama, masih rendahnya kemahiran membaca anak. Kedua, sistem pembelajaran di Indonesia belum membuat anak harus membaca buku (lebih banyak lebih baik). Ketiga, banyaknya jenis hiburan, permainan dan tayangan TV yang dapat mengalihkan perhatian anak dan orang dewasa dari buku. Keempat, banyaknya tempat hiburan yang menghabiskan waktu seperti taman rekreasi. Kelima, faktor eksternal, diantaranya berhubungan dengan tingkat daya beli masyarakat yang rendah (Shofaussamawati, 2014).

Pengembangan budaya baca di masyarakat tidak hanya ditentukan oleh keinginan dan sikap terhadap bahan bacaan, tetapi juga ditentukan oleh ketersediaan dan kemudahan akses ke bahan bacaan. Ketersediaan bahan bacaan berarti ketersediaan bahan bacaan yang memenuhi, kebutuhan masyarakat. Sementara aksesibilitas adalah ketersediaan sarana dan prasarana di mana orang dapat dengan mudah memperoleh 


\section{6 | Arif Khoiruddin, Imam Taulabi, Ali Imron | Menumbuhkan minat baca}

bahan bacaan dan informasi tentang bahan bacaan. Taman baca masyarakat yang ada belum dimanfaatkan secara maksimal dan optimal oleh masyarakat. Sebagian taman baca masyarakat yang kurang diminati oleh warga belajar lebih pada karena pengelolaan yang kurang maksimal dan kurangnya motivasi masyarakat untuk membaca (Hapsari, 2009).

\section{Kesimpulan}

Kegiatan pendampingan ini menghasilkan kesimpulan sebagai berikut. Taman Baca Masyarakat (TBM) keberadaanya sebagai media dalam rangka meningkatkan minat baca pada anak usia dini melakukan beberapa kegiatan; kegiatan lomba memasak, bazar buku dan baju bekas, lomba menggambar, lomba mewarnai, membaca cerita dan mendongeng, pelatihan membaca cerita. Di samping itu ada serangkaan penataan di TBM misalnya, membuat rak buku, menambah buku-buku bacaan untuk anak, perbaikan sistem pengelolaan taman baca, pengorganisasian taman baca, desain ruangan dengan memberi gambar dan beberapa tulisan-tulisan mengandung pesan moral.

Kegiatan pengabdian kepada masyarakat, ini disisi dengan beberapa rangkaian kegiatan. Langkah-langkah tersebut dilakukan untuk mengumpulkan anak-anak dan orang tua untuk datang ke taman baca, sehingga mereka tahu bahwa ada banyak bacaan dengan adanya ketertarikan mereka pada buku dan bahan bacaan lainnya diharpakan dapat mendorong anak-anak untuk gemar membaca. Kegiatan ini lebih diorantasikan anak usia dini dengan harapan bahwa kegemaran membaca harus ditumbuh kembangkan sejak mereka usia dini, usia antara 5-7 tahun. 
Arif Khoiruddin, Imam Taulabi, Ali Imron | Menumbuhkan minat baca | 317

\section{Saran-Saran}

Adapun saran-saran yang dapat disampaikan sebagai berkut:

1. Untuk pengelola taman baca, bahwa kerja sosial yang dilakukan oleh teman-teman tidak akan mendapathan hasil secara langsung, sehingga kesabaran dan kansitensi kunci utamanya,

2. Pengelola perlu mengadakan berbagai kegiatan yang lebih banyak, krataif, inovatif agar semnagat anak mengujungi taman baca tidak pudar,

3. Orang tua yang memiliki anak kecil disarankan untuk mengajak anak-anaknya agar mengenal sumber-sumber bacaan, dan disela-sela waktu luang liburan alangkah lebih baiknya menyempatkan diri untuk berkunjung ke taman baca.

\section{Ucapan Terima Kasih}

Kami sampaikan banyak terima kasih kepada Kementerian Agama Republik Indonsesia yang telah memberi Dana Hibah Bantuan Peningkatan Mutu Pengabdian Kepada Masyarakat Direktorat Pendidikan Tinggi Islam Direktorat Jenderal Pendidikan Islam Kementerian Agama RI Tahun 2016. 


\section{DAFTAR PUSTAKA}

Anderson, J., Friedrich, A., Kim J. E, n.d. Taking stock of family literacy: Some contemporary perspectives. J. Early Child. Lit. 1, 2010.

Bingham, Pennington, 2007. As Easy as ABC: Facilitating early

literacy enrichment experiences. Young Exceptional

Children 10.

Departemen Pendidikan Nasional, 2008. Naskah Akademik

Pengelola Taman Bacaan Masyarakat (TBM). Direktorat

Jenderal Peningkatan Mutu Pendidik dan Tenaga

Kependidikan, Jakarta.

Dewi, C.R., 2010. Peran serta Taman Bacaan Masyarakat sebagai

Modal Terwujudnya Surabaya sebagai Kota baca

Memasuki Era Globalisasi. Direktorat Pendidik dan

Tenaga Kependidikan Nonformal, Jakarta.

Hapsari, M.I., 2009. Analisis sistemik penyelenggaraan taman

bacaan masyarakat di kabupaten semarang. J. PNFI 1.

Hidi, 2001. Interest, Reading, and Learning: Theoritical and

Practical Consideration. Educ. Psychol. Rev. 13.

Hurlock, 2007. Perkembangan Anak Jilid 1 Edisi Keenam. Terj.

Med.Meitasari Tjandrasa dan Muslichah Zarkasih.

Erlangga, Jakarta.

Karim, A., 2014. Mengembangkan berpkir kreatif melalui membaca dengan model mind map. J. Perpust. Libr. 2.

Kumoro, I., 2015. Analisis urgensi metode pembelajaran bercerita bagi perkembangan empati anak di tk dharma wanita kendal tahun ajaran 2015/2016.

Marini, K., Pudjawan, K., Asril, N.M., 2015. Penerapan metode bercerita berbantuan media boneka tangan untuk meningkatkan keterampilan berbicara pada anak kelompok B3. Jur. Pendidik. Guru Pendidik. Anak Usia Dini 3.

Moeslichatoen, 2004. Metode Pengajaran di Taman Kanakkanak. PT. Rineka Cipta, Jakarta. 
Muallifah, 2013. Storytelling sebagai metode parenting untuk pengembangan kecerdasan anak usia dini. J. Psikoislamika 10.

Mulyani, 1981. Pembinaan Minat Baca dan Promosi

Perpustakaan. Ber. Perpust. Sekol.

Nur'aini, F., 2008. Edu Games for Childs. Afra Publising, Surakarta.

Rahman, M.M., 2013. Metode bercerita membentuk kepribadian muslim pada anak usia dini. ThufuLa 1.

Ruhaena, L., 2016. Stimulasi literasi anak prasekolah masalah dan solusinya. Asean Conference 2nd Psychology \&

Humanity: Optimalizing Human Strenght for Productivity and Well Being. UMM, Malang.

Ruhaena, L., 2015. Model multisensory: solusi stimulasi literasi anak prasekolah. J. Psikol. 2.

Ruhaena, L., 2012. Model stimulasi dini kemampuan baca tulis anak prasekolah di rumah. UMS, Surakarta.

Ruhaena, L., 2011. Profil minat literasi orang tua dan anak prasekolah. UGM, Yogyakarta.

Shofaussamawati, 2014. Menumbuhkan minat baca dengan pengenalan perpustakaan pada anak sejak dini. J. Perpust. Libr. 2.

Siswati, 2010. minat membaca pada mahasiswa (Studi Deskriptif pada Mahasiswa Fakultas Psikologi UNDIP Semester I). J. Psikol. Undip 8.

Spradly, J.P., 2006. Metode Etnografi. terjmahan oleh Misbah Zulfah Elizabeth dari The Ethnographic Interview (1979). Tiara Wacana, Yogyakarta.

Supartini, Y., 2004. Buku ajar konsep Keperawatan Anak. ECC, Jakarta.

Survei UNESCO: Minat Baca Masyarakat Indonesia 0,001 Persen [WNNW Document], 2016. . Go Bekasi. URL http://gobekasi.pojoksatu.id/2016/05/19/survei-unescominat-baca-masyarakat-indonesia-0001-persen/ (accessed 3.3.17). 